\title{
The muscle protein dysferlin accumulates in the Alzheimer brain
}

\author{
James E. Galvin • Divya Palamand • Jeff Strider • \\ Margherita Milone • Alan Pestronk
}

Received: 3 March 2006 / Revised: 5 September 2006 / Accepted: 5 September 2006 / Published online: 6 October 2006

(C) Springer-Verlag 2006

\begin{abstract}
Dysferlin is a transmembrane protein that is highly expressed in muscle. Dysferlin mutations cause limb-girdle dystrophy type 2B, Miyoshi myopathy and distal anterior compartment myopathy. Dysferlin has also been described in neural tissue. We studied dysferlin distribution in the brains of patients with Alzheimer disease (AD) and controls. Twelve brains, staged using the Clinical Dementia Rating were examined: 9 AD cases (mean age: 85.9 years and mean disease duration: 8.9 years), and 3 age-matched controls (mean age: 87.5 years). Dysferlin is a cytoplasmic protein in the pyramidal neurons of normal and AD brains. In addition, there were dysferlin-positive dystrophic neurites within $\mathrm{A} \beta$ plaques in the $\mathrm{AD}$ brain, distinct from taupositive neurites. Western blots of total brain protein (RIPA) and sequential extraction buffers (high salt,
\end{abstract}

J. E. Galvin $(\bowtie) \cdot$ D. Palamand · J. Strider

Alzheimer Disease Research Center,

Washington University School of Medicine,

4488 Forest Park, Suite 130, St Louis, MO 63108, USA

e-mail: galvinj@neuro.wustl.edu

J. E. Galvin · D. Palamand · J. Strider · M. Milone ·

A. Pestronk

Department of Neurology,

Washington University School of Medicine,

St Louis, MO, USA

J. E. Galvin

Department of Anatomy and Neurobiology,

Washington University School of Medicine,

St Louis, MO, USA

Present Address:

M. Milone

Department of Neurology, Mayo Clinic,

Rochester, MN, USA high salt/Triton X-100, SDS and formic acid) of increasing protein extraction strength were performed to examine solubility state. In RIPA fractions, dysferlin was seen as $230-272 \mathrm{kDa}$ bands in normal and AD brains. In serial extractions, there was a shift of dysferlin from soluble phase in high salt/Triton X-100 to the more insoluble SDS fraction in AD. Dysferlin is a new protein described in the AD brain that accumulates in association with neuritic plaques. In muscle, dysferlin plays a role in the repair of muscle membrane damage. The accumulation of dysferlin in the AD brain may be related to the inability of neurons to repair damage due to $\mathrm{A} \beta$ deposits accumulating in the $\mathrm{AD}$ brain.

Keywords Dysferlin A Alzheimer's disease - Amyloid $\beta$-protein · Tau protein $\cdot$ Protein aggregation .

Neurodegeneration

\section{Introduction}

Aggregation of neuronal proteins is a common mechanistic theme in neurodegenerative diseases [13]. Whether due to point mutations or post-translational modification, normally soluble proteins are altered and form insoluble fibrillar aggregates [18]. Alzheimer's disease (AD), the most common form of dementia, is characterized pathologically by abundant diffuse and neuritic plaques throughout most cortical regions. Amyloid $\beta$-protein $(\mathrm{A} \beta)$ is a $39-43$ amino acid peptide cleaved from a larger precursor protein (amyloid precursor protein or APP) that deposits extracellularly as senile plaques either as loose, nonfibrillar diffuse plaques, or as a more compacted, fibrillar form, with dystrophic neurites coursing through the plaque [25]. 
Other aggregated proteins found in the AD brain include the microtubule-associated protein tau [11] as neurofibrillary tangles and the presynaptic protein $\alpha$ synuclein [13] in the form of Lewy bodies.

The alteration, deposition and aggregation of amyloid proteins may be an ill-fated response to the disease process or themselves lead to a cascade of cellular responses ultimately resulting in neuronal dysfunction and death.

Nonbrain protein aggregates have been described in muscle disease. For example, amyloid-like deposits have been described in inclusion body myositis [2]. Other protein aggregates found in muscle disease include desmin-related myopathies, actinopathies and myosinopathies [30]. Aggregates containing these proteins have not been described in brain disease. Another muscle protein associated with myopathy is dysferlin. Dysferlin is a plasma membrane and cytoplasmic vesicle-associated protein implicated in three adult-onset muscle diseases (limb-girdle dystrophy, type 2B, Miyoshi myopathy and distal anterior compartment myopathy) $[4,9,22,24]$. Although described in peripheral nerve [30] and demonstrated by Western blot in human and mouse brain [21], there is little known about the function of dysferlin in the brain or its role in neurodegenerative disease. We describe the pattern of dysferlin expression in the normal and AD brain and examine dysferlin accumulation in association with amyloid deposition in the brains of AD patients.

\section{Materials and methods}

Case materials

Case materials were derived from research participants in a longitudinal study of healthy aging and dementia who were studied postmortem. The diagnostic criteria are consistent with probable $\mathrm{AD}$ reported by the National Institute of Neurological and Communicative Disorders and Stroke and Alzheimer's Disease and Related Disorders Association [26] and confirmed by autopsy to meet high probability of AD according to National Institute of Aging-Reagan criteria [28]. The clinical dementia rating (CDR) was used to determine the presence or absence of dementia and stage its severity [27]. The global CDR is derived by a synthesis of individual ratings in six cognitive and functional categories where $\mathrm{CDR}=0$ indicates no dementia and $\mathrm{CDR}=0.5,1,2$, or 3 corresponds to very mild, mild, moderate, or severe dementia [27]. The CDR is closely correlated with the presence of dementia pathology at autopsy [14]. The Washington University Human Studies Committee approved all procedures.

Twelve brains were examined. Three cases were rated as nondemented (CDR 0) with a mean age of 87.5 years. Nine AD brains were examined; three each of mild (CDR 1), moderate (CDR 2) and severe (CDR $3)$. The mean age of the demented cases was 85.9 years with mean disease duration of 8.9 years (Table 1 ). Control cases were all Braak stage I or II [6]. Sampling during postmortem exam was done from 29 different cortical, subcortical and brainstem regions. Paraffinembedded sample for this study were taken from midfrontal, cingulate and entorhinal regions; three sections were stained for each antibody with appropriate controls [15]. Biochemistry was performed on midfrontal gyrus adjacent to the section taken for immunohistochemistry for each case.

Immunohistochemistry

Immunohistochemistry was done as previously described $[14,15]$. Briefly, serial $6 \mu \mathrm{m}$ sections of para-

Table 1 Sample characteristics and findings at postmortem examination

\begin{tabular}{|c|c|c|c|c|c|c|c|c|c|}
\hline \multirow[t]{2}{*}{ Case } & \multirow{2}{*}{$\begin{array}{l}\text { Age } \\
\text { (years) }\end{array}$} & \multirow[t]{2}{*}{ Sex } & \multirow[t]{2}{*}{ CDR } & \multirow{2}{*}{$\begin{array}{l}\text { Disease } \\
\text { duration } \\
\text { (years) }\end{array}$} & \multirow{2}{*}{$\begin{array}{l}\text { Brain } \\
\text { wt }(g)\end{array}$} & \multicolumn{2}{|l|}{ Braak scores } & \multirow{2}{*}{$\begin{array}{l}\text { CERAD } \\
\text { criteria }\end{array}$} & \multirow{2}{*}{$\begin{array}{l}\text { NIA-Reagan } \\
\text { criteria }\end{array}$} \\
\hline & & & & & & Neurofibrillary & Amyloid & & \\
\hline 1 & 92 & $\mathrm{~F}$ & 0 & - & 1,120 & II & A & - & - \\
\hline 2 & 85 & $\mathrm{~F}$ & 0 & - & 1,100 & $\mathrm{I}$ & A & - & - \\
\hline 3 & 92 & $\mathrm{~F}$ & 0 & - & 1,210 & I & A & - & - \\
\hline 4 & 85 & $\mathrm{~F}$ & 1 & 8 & 1,200 & IV & $\mathrm{C}$ & Definite & High \\
\hline 5 & 99 & M & 1 & 2 & 1,230 & $\mathrm{~V}$ & $\mathrm{~B}$ & Definite & High \\
\hline 6 & 95 & $\mathrm{M}$ & 1 & 14 & 1,360 & $\mathrm{~V}$ & $\mathrm{C}$ & Definite & High \\
\hline 7 & 81 & $\mathrm{M}$ & 2 & 16 & 790 & VI & $\mathrm{C}$ & Definite & High \\
\hline 8 & 91 & $\mathrm{M}$ & 2 & 11 & 1,580 & $\mathrm{~V}$ & $\mathrm{~B}$ & Definite & High \\
\hline 9 & 90 & M & 2 & 7 & 1,170 & IV & B & Definite & High \\
\hline 10 & 86 & M & 3 & 10 & 1,310 & VI & $\mathrm{C}$ & Definite & High \\
\hline 11 & 79 & $\mathrm{~F}$ & 3 & 8 & 770 & VI & $\mathrm{C}$ & Definite & High \\
\hline 12 & 88 & M & 3 & 11 & 1,130 & VI & $\mathrm{C}$ & Definite & High \\
\hline
\end{tabular}


formaldehyde-fixed, paraffin-embedded tissue were prepared and incubated overnight at $4{ }^{\circ} \mathrm{C}$ with antibodies against dysferlin (Novacastra Laboratories), tau (17026, gift from J. Trojanowski), and amyloid $\beta$ protein (6E10, Signet). Sections were developed by avidin-biotin complex method (Vector Laboratories) for immunohistochemistry with DAB (brown), Vector Red (pink) and Vector SG (blue) as chromogens. Alexa-Red and Green (Jackson Laboratories) antibodies were used for immunofluorescence. Sections were examined with a Nikon E800 Research microscope, and images were digitized and viewed with AnalySIS analytic software (Soft Imaging Systems, GmbH).

\section{Western blots}

Western blotting and biochemical fractionation were performed as described previously [16]. Briefly, two sections of gray matter $(0.3 \mathrm{~g})$ from the midfrontal cortex of $\mathrm{AD}$ and normal age-matched control brains were dissected from underlying white matter. After dissection, gray matter was divided into two samples (Fig. 1). One sample was homogenized in RIPA $(150 \mathrm{mM} \mathrm{NaCl}, 0.1 \% \mathrm{SDS}, 0.5 \%$ sodium deoxycholate, $1 \%$ NP-40, $50 \mathrm{mM}$ Tris, $\mathrm{pH} 8,20 \mathrm{mM}, \mathrm{NaF}, 2 \mathrm{mM}$ EGTA, $0.5 \%$ levamisole, $1 \mathrm{mM} \mathrm{NaVO} 4)$ to estimate total dysferlin. The other sample was homogenized and subjected to sequential extraction buffers of increasing protein extraction strength. For each buffer, pellets were washed twice and supernatants pooled. Samples were first homogenized in $2 \mathrm{ml} / \mathrm{gram}$ of tissue of high-salt

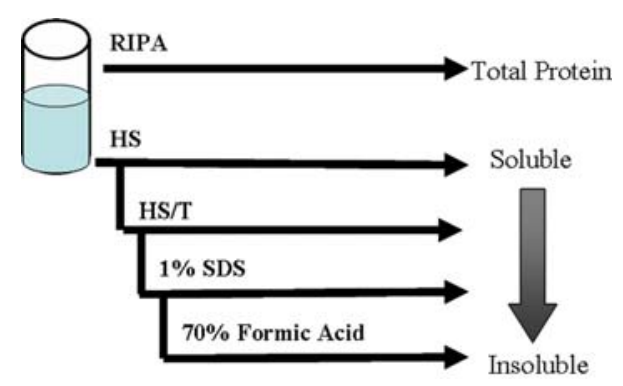

Fig. 1 Schematic representation of sequential protein extraction buffers. Samples are divided into equal portions. The first sample is homogenized in RIPA buffer and blotted to estimate total dysferlin levels. The other sample is homogenized in sequential extraction buffers of increasing protein extraction strength. The first extraction is in high-salt $(H S)$ buffer. The supernatants are saved and the pellet is extracted with HS buffer/1\% Triton X-100 (HS/T) buffer. After saving the supernatants, the resultant pellet is homogenized in sodium dodecyl sulfate $(S D S)$ sample buffer. Resulting pellets are finally extracted with $70 \%$ formic acid $(F A)$. Supernatants are blotted to estimate differing levels of dysferlin solubility with the HS fraction representing the most soluble phase and the FA fraction representing the most insoluble phase
(HS) buffer $(50 \mathrm{mmol} / \mathrm{l}$ Tris, $\mathrm{pH} 7.4,750 \mathrm{mmol} / \mathrm{l} \mathrm{NaCl}$, $10 \mathrm{mmol} / \mathrm{l} \mathrm{NaF}, 5 \mathrm{mmol} / \mathrm{l}$ ethylenediaminetetraacetic acid with protease inhibitors) and centrifuged at $100,000 \mathrm{~g}$ for $30 \mathrm{~min}$. The pellets were re-extracted and the supernatants were pooled. The pellets were sequentially extracted twice with $2 \mathrm{ml} / \mathrm{gram}$ of $\mathrm{HS}$ buffer/1\% Triton X-100 (HS/T) and once with $1 \mathrm{ml} /$ gram sodium dodecyl sulfate (SDS) sample buffer $(1 \%$ SDS, $10 \%$ sucrose, $10 \mathrm{mmol} / 1 \mathrm{Tris}, \mathrm{pH} 6.8,1 \mathrm{mmol} / \mathrm{l}$ ethylenediaminetetraacetic acid, $40 \mathrm{mmol} / \mathrm{l}$ dithiothreitol). The pellets were extracted with $0.67 \mathrm{ml} / \mathrm{g} 70 \%$ formic acid (FA) and disrupted with two sequential 2-s sonication bursts. FA was evaporated in a vacuum centrifuge (Eppendorf). SDS sample buffer $(0.67 \mathrm{ml} / \mathrm{g})$ was added to the dried pellets, followed by vigorous vortex, and the $\mathrm{pH}$ was adjusted with $\mathrm{NaOH}$. SDS sample buffer was added to the HS and HS/Triton fraction and all of the samples were boiled for $5 \mathrm{~min}$. The FA samples were centrifuged at $13,000 \mathrm{~g}$ for $5 \mathrm{~min}$ to remove insoluble debris. Five microliters of each fraction was loaded in separate lanes for SDS-polyacrylamide gel electrophoresis followed by Western blot analysis with antibodies again dysferlin. The immune complexes were visualized with the use of the ECL Plus kit (Amersham) according to the manufacturer's protocol. The autoradiographs obtained were scanned and the band intensity quantified utilizing TotalLab software (Nonlinear Dynamics, Newcastle on Tyne, UK). Statistical analyses were performed by analysis of variance using SPSS statistical software.

\section{Results}

Localization of dysferlin in normal (CDR 0) brain

Microscopic evaluation of the dysferlin staining in the normal (CDR 0) brain localized expression to the cytoplasm of large pyramidal neurons of layers III, $\mathrm{V}$ and VI in the neocortex (Fig. 2a), layer II neurons of the entorhinal cortex, CA 1-3 neurons in the hippocampus and large projection neurons in the amygdala (not shown). Dysferlin was not localized to astrocytes, endothelial cells or microglia (arrowheads in Fig. 2b). Little to no dysferlin neuritic staining was seen in control cases (Braak stage I or II).

\section{Dysferlin in the AD brain}

Dysferlin neuritic accumulation is found throughout the AD brain and in double-label studies it is localized in $A \beta$ neuritic plaques in the neocortex (Fig. 3a). Double-labeled studies demonstrate co-localization of 

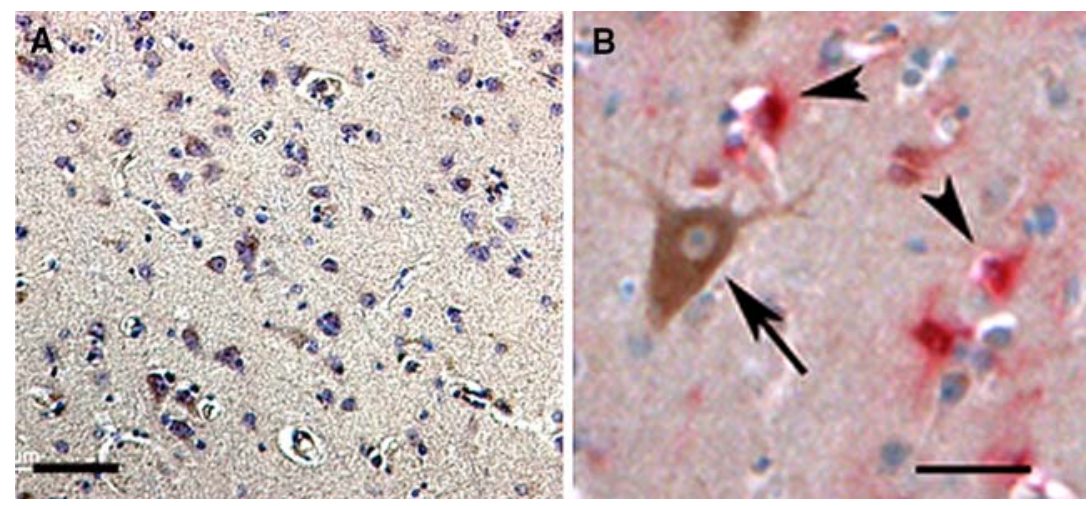

Fig. 2 Localization of dysferlin in brains of nondemented subjects. a, b Demonstrates the localization of dysferlin immunoreactivity in the brain. There is a neuronal expression of dysferlin localized in cytoplasm of large pyramidal (layers III, V, VI) neurons in the frontal cortex at low power (a). Little to no neuritic

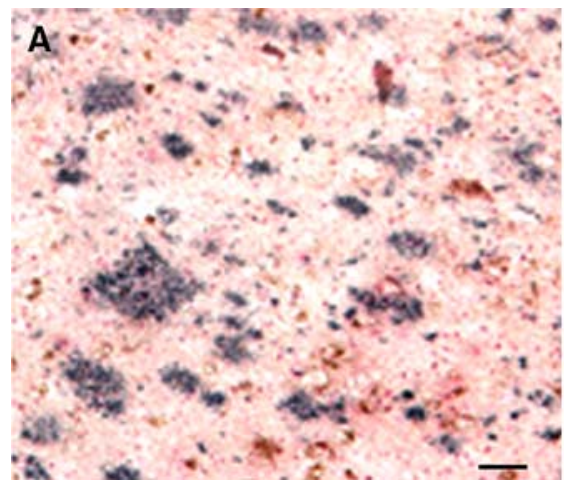

Fig. 3 Localization of dysferlin with amyloid pathology in the AD brain. a, b Demonstrates the location of the dysferlin accumulation in the AD brain with double-labeled studies. a Diffuse dysferlin accumulation (DAB, brown) and $\mathrm{A} \beta$ (DAB-nickel, black) in the frontal cortex. Using VectorRed (pink, Vector Laboratories) as the chromogen for $\mathrm{A} \beta$ and DAB (brown, Vector

dysferlin (brown in Fig. 3b) and $A \beta$ (pink in Fig. 3b) in the hippocampus.

Dysferlin neuritic pathology occurs in conjunction with tau neuritic pathology

In Fig. 4, we demonstrate that neurites in plaques may comprise tau, dysferlin or both. Triple-labeled studies of midfrontal (Fig. 4a), cingulate (Fig. 4b) and entorhinal (Fig. 4c) cortex illustrate the relationship of tau (pink, arrowheads) and dysferlin (brown, arrows) within an $\mathrm{A} \beta$ plaque (blue). Double-labeled immunofluorescent studies (Fig. 4d-f) demonstrate that tau (green in 4d) and dysferlin (red in Fig. 4e) have both distinct and overlapping (yellow in Fig. 4f) epitopes in neuritic plaques. Dysferlin does not appear to co-localize with the more abundant tau dystrophic neurites. staining was detected. Dysferlin expression is confined to neurons (arrow, DAB brown in b) and is not seen in glial cells stained with GFAP (small arrowheads, Vector Red pink in b). Magnification of (a) is $100 \times$ and the scale bar in (a) $=50 \mu \mathrm{m}$. Magnification of (b) is $400 \times$ and the scale bar in $(\mathbf{b})=20 \mu \mathrm{m}$

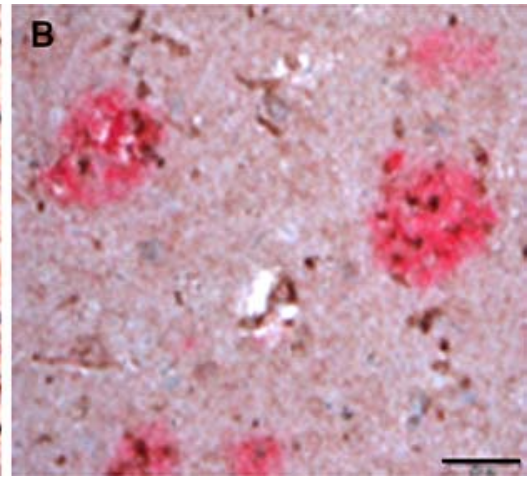

Laboratories) as the chromogen for dysferlin, the pathologic deposition is localized as neuritic pathology in $A \beta$ neuritic plaques in the neocortex hippocampus (b). Magnification of (a) is $100 \times$ and the scale bar in $(\mathbf{a})=20 \mu \mathrm{m}$. Magnification of $(\mathbf{b})$ is $200 \times$ and the scale bar in $(\mathbf{b})=20 \mu \mathrm{m}$

\section{Biochemistry}

Western blot analysis following RIPA extraction demonstrated the presence of dysferlin as $230-272 \mathrm{kDa}$ bands in all brains examined (Fig. 5a); however, there was a decrease in the total dysferlin content in CDR 3 (severe AD) brains compared to CDR 0 (nondemented). There is a progressive decrease in total dysferlin with progressive disease $(r=0.998, P=0.001)$. Western blot analysis following serial extraction of proteins demonstrated a change in the solubility state of dysferlin across the spectrum of dementia (Fig. 5b). No dysferlin could be demonstrated in the HS fraction. In contrast to the control CDR 0 brains, however, there was a significant reduction of dysferlin in the HS/ $\mathrm{T}$ fraction in the demented cases (CDR 1 and 2) and was undetectable at the CDR 3 level of severity 

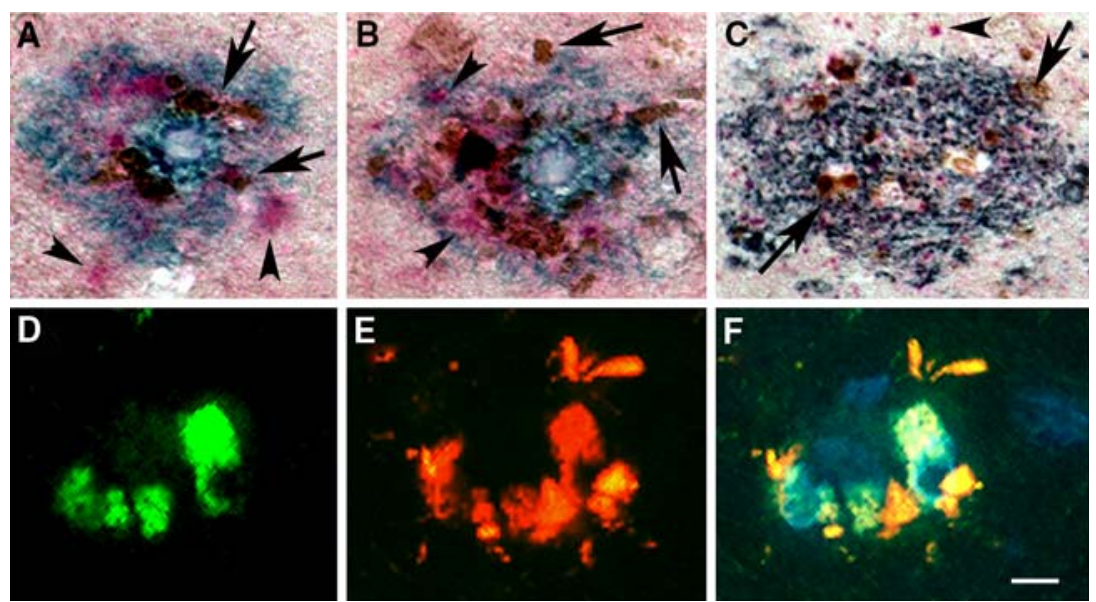

Fig. 4 Localization of dysferlin with tau pathology in the AD brain. a-f Demonstrates the location of the dysferlin and tau accumulation in the AD brain with triple-labeled immunohistochemistry studies $(\mathbf{a}-\mathbf{c})$ and double-labeled immunofluorescence studies (d-f). a Midfrontal, b cingulate and $\mathbf{c}$ entorhinal demonstrate tau (Vector Red, pink, arrowheads), dysferlin (DAB, brown, arrows) and A $\beta$ (Vector SG, blue). Note the distinction between tau-positive and dysferlin-positive structures. Doublelabeled immunofluorescence studies demonstrated neurites within amyloid plaques. Neurites may comprise tau (green, d), dysferlin $(\mathrm{red}, \mathbf{e})$ or overlapping epitopes (yellow in merged image of $\mathbf{f}$ ). Magnification of $(\mathbf{a}-\mathbf{f})$ is $600 \times$ and the scale bar in $(\mathbf{d})=20 \mu \mathrm{m}$
$(F=2,991, P<0.001)$. In the SDS-soluble fraction from the demented cases, there was an accumulation of $230-272 \mathrm{kDa}$ bands with dementia progression, that is a more insoluble form of dysferlin was found in severe CDR 3 brains compared to milder stages of dementia (CDR 1) or in nondemented individuals $(F=3,183$, $P<0.001)$. Dysferlin did not aggregate or accumulate in the FA-soluble fractions of the control or $\mathrm{AD}$ brains.

\section{Discussion}

Dysferlin is a new protein described in the AD brain associated with neuritic plaques. Dysferlin is widely expressed in the brain and is found in intracytoplasmic compartments in pyramidal neurons in normal brains. Dysferlin begins to accumulate in dystrophic neurites in the AD brain at mild stages of dementia (CDR 1). Dysferlin is found at all stages of disease with greater accumulation in more advanced disease (CDR 3).

Significantly, our Western blot analysis demonstrated dysferlin in RIPA-extracted fraction in all cases; however, in the serial extracted fractions an alteration in the solubility state of dysferlin was found in demented cases (CDR $>1)$ compared with nondemented cases. This coincides with the finding of neuritic pathology by immunohistochemistry. The HS/T fraction represents the transmembrane cytoskeletal fraction of normal dysferlin and decreases with advanced stages of dementia. This may represent the loss of membrane integrity and alteration in cytoskeleton structure. In contrast, the SDS-soluble fraction represents more insoluble forms of the protein suggesting aggregation of dysferlin may be related to disease progression. This alteration of solubility and accumulation is seen in other neurodegenerative diseases (e.g. Parkinson's disease, multiple system atrophy, dementia with Lewy bodies) [15, 31].

Dysferlin is a member of ferlin family, homologous to fer1 protein in C. elegans [5]. It is highly expressed in muscle but little is known about the role of the protein in the brain. Several members of the ferlin family have been mapped. Dysferlin is found on chromosome 2p13 [1] and deficiency is associated with three clinical phenotypes: Limb-Girdle muscular dystrophy, type 2B, Miyoshi myopathy and distal anterior compartment myopathy [20, 22, 24]. Another member of the ferlin family, Otoferlin is mapped to chromosome 2p23 and is associated with autosomal recessive nonsyndromic deafness [31]. Two other members of the ferlin family have been described: Myoferlin (10q24) [7] and FerlL4 (20q11) [12]. Myoferlin is a type II transmembrane protein upregulated in Duchenne muscular dystrophy and may have a role in muscle regeneration and repair [10]. The function of Fer1L4 is unknown.

Dysferlin is thought to play a role in muscle membrane maintenance and repair $[3,4,9,12,19]$. In C. elegans, the Fer1 protein plays a role in vesicle trafficking and membrane fusion and can bind to phospholipids in a calcium-dependent manner [22]. In dysferlin null-mice, muscle cells are defective in repairing membrane disruptions leading to degeneration [4, 21, 23]. If dysferlin has a similar membrane repair function in neurons, then it is 
A
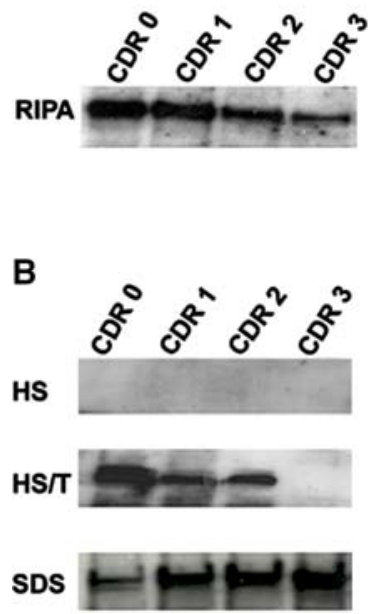

RIPA

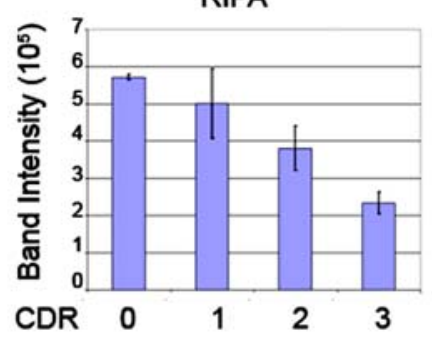

HS/T vs. SDS Solubility

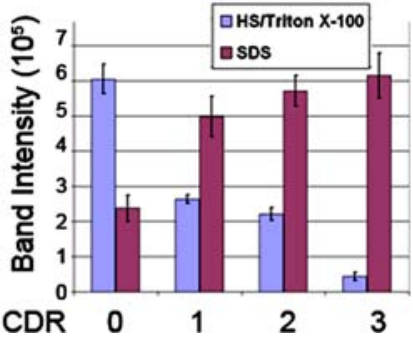

Fig. 5 Western Blot analysis of dysferlin in nondemented and AD brains. a Nondemented $(C D R \quad 0)$ and AD brains $($ mild $=C D R 1$, moderate $=C D R 2$, and severe $=C D R 3)$ were extracted in RIPA as described in the Materials and methods. Five microliters of each extraction were loaded into separate lanes of a $12 \%$ SDS-polyacrylamide gel electrophoresis and after transfer to nitrocellulose membranes were probed with antibodies against dysferlin. The blot demonstrates the presence of dysferlin in both normal and AD brains with declining levels of protein across disease progression. Band intensities were quantified and compared in a bar graph. There is a linear decrease in total dysferlin associated with disease progression $(r=0.998$, $P=0.001)$. b The same brains were sequentially extracted with HS, HS/T, SDS and FA as described in the Materials and methods section as loaded onto $12 \%$ SDS-polyacrylamide gel electrophoresis as described earlier. Dysferlin was not seen in either the HS or FA fractions. Dysferlin was demonstrated prominently in $\mathrm{HS} / \mathrm{T}$ fraction in the $C D R O$ brains, with a significant reduction $(F=2,991, P<0.001)$ of dysferlin in the HS/T fraction in the demented cases (CDR 1 and 2) and was nearly undetectable in severe $\mathrm{AD}(C D R 3)$ In contrast, the SDS fraction representing insoluble phases of dysferlin demonstrated significant increases $(F=3138, P<0.001)$ in the $230-272 \mathrm{kDa}$ bands as dementia progressed from mild $(C D R 1)$ to severe $(C D R 3)$

possible that the deposition of dysferlin in AD may be related to the inability of neurons to repair damage due to accumulating $A \beta$ pathology throughout the progression of $\mathrm{AD}$. The findings reported suggest that there may be common mechanisms of membrane repair in degenerative diseases of muscle (e.g. dystrophinopathies and sarcoglycanopathies) and brain (e.g. AD).

The aggregation of normally soluble proteins in fibrillar lesions is the neuropathologic hallmark of many neurodegenerative diseases. Whether the aggregates or their precursors are the actual toxic species is still under debate [8]; however, it is likely that the conversion of proteins from a soluble to insoluble state impairs the long-term viability of neurons. In addition,

because dysferlin appears to accumulate in conjunction with $\mathrm{A} \beta$ deposition and disease progression it may be able to serve as a marker of disease progression. Continued efforts aimed at understanding abnormalities in the misfolding of protein leading to neurodegenerative disease such as $A \beta$ and tau, or proteins associated with aggregation such as dysferlin will provide insights into disease mechanisms underlying neurological disorders characterized by abundant filamentous lesions.

Acknowledgments The authors would like to acknowledge the clinical and neuropathology cores of the Alzheimer Disease Research Center at Washington University for their expert characterization of the clinical and pathological material. This work was supported by grants from the National Institute on Aging (K08 AG20764, P01 AG05681, P50 AG03991), the American Federation for Aging Research and a generous gift from the Alan A. and Edith L. Wolff Charitable Trust. Dr. Galvin is a recipient of the Paul Beeson Physician Faculty Scholar in Aging Research Award.

\section{References}

1. Aoki M, Liu J, Richard I, Bashir R, Britton S, Keers SM, Oeltjen J, Brown HE, Marchand S, Bourg N, Beley C, McKenna-Yasek D, Arahata K, Bohlega S, Cupler E, Illa I, Majneh I, Barohn RJ, Urtizberea JA, Fardeau M, Amato A, Angelini C, Bushby K, Beckmann JS, Brown RH Jr (2001) Genomic organization of the dysferlin gene and novel mutations in Miyoshi myopathy. Neurology 57:271-278

2. Askanas V, Engel WK (2003) Proposed pathogenetic cascade of inclusion-body myositis: importance of amyloid-beta, misfolded proteins, predisposing genes, and aging. Curr Opin Rheumatol 15:737-744

3. Bansal D, Campbell KP (2004) Dysferlin and the plasma membrane repair in muscular dystrophy. Trends Cell Biol 14(4):206-13

4. Bansal D, Miyake K, Vogel SS, Groh S, Chen CC, Williamson R, McNeil PL, Campbell KP (2003) Defective membrane repair in dysferlin-deficient muscular dystrophy. Nature 423:168-172

5. Bashir R, Britton S, Strachan T, Keers S, Vafiadaki E, Lako M, Richard I, Marchand S, Bourg N, Argov Z, Sadeh M, Mahjneh I, Marconi G, Passos-Bueno MR, Moreira Ede S, Zatz M, Beckmann JS, Bushby K (1998) A gene related to Caenorhabditis elegans spermatogenesis factor fer-1 is mutated in limb-girdle muscular dystrophy type 2B. Nat Genet 20:37-42

6. Braak H, Alafuzoff I, Arzberger T, Kretzschmar H, Del Tredici K (2006) Staging of Alzheimer disease-associated neurofibrillary pathology using paraffin sections and immunocytochemistry. Acta Neuropathol, PMID: 16906426

7. Britton S, Freeman T, Vafiadaki E, Keers S, Harrison R, Bushby K, Bashir R (2000) The third human FER-1-like protein is highly similar to dysferlin. Genomics 68:313-321

8. Caughey B, Lansbury PT Jr (2003) Proto fibrils, pores, fibrils, and neurodegeneration: separating the responsible protein aggregates from the innocent bystanders. Annu Rev Neurosci 26:267-298

9. Cenacchi G, Fanin M, De Giorgi LB, Angelini C (2005) Ultrastructural changes in dysferlinopathy support defective membrane repair mechanism. J Clin Pathol 58:190-195 
10. Davis DB, Delmonte AJ, Ly CT, McNally EM (2000) Myoferlin, a candidate gene and potential modifier of muscular dystrophy. Hum Mol Genet 9:217-226

11. Dermaut B, Kumar-Singh S, Rademakers R, Theuns J, Cruts M, Van Broeckhoven C (2005) Tau is central in the genetic Alzheimer-frontotemporal dementia spectrum. Trends Genet 21:664-672

12. Doherty KR, McNally EM (2003) Repairing the tears: dysferlin in muscle membrane repair. Trends Mol Med 9:327-330

13. Galvin JE, Lee VM-Y, Trojanowski JQ (2000) Synucleinopathies: Clinical and pathological implications. Arch Neurol 58:186-190

14. Galvin JE, Powlishta KK, Wilkins K, McKeel Jr DW, Storandt M, Grant E, Morris JC (2005) Predictors of preclinical Alzheimer disease and dementia: a clinicopathologic study. Arch Neurol 62:758-765

15. Galvin JE (2003) Detection of aggregates and protein inclusions by staining of tissues. Methods Mol Biol 232:149-164

16. Galvin JE, Giasson BI, Hurtig HI, Lee VMY, Trojanowski JQ (2000) Neurodegeneration with brain iron accumulation, type 1 (NBIA 1 ) is characterized by $\alpha-, \beta$-, and $\gamma$-synuclein neuropathology. Am J Pathol 157:361-368

17. Galvin JE (2004) Gene expression profiling the neuropathology of neurodegenerative disease. Neurochem Res 29:10411051

18. Goedert M (1999) Filamentous nerve cell inclusions in neurodegenerative diseases: tauopathies and alpha-synucleinopathies. Philos Trans R Soc Lond B Biol Sci 354:1101-1118

19. Hayashi YK (2003) Membrane-repair machinery and muscular dystrophy. Lancet 362:843-844

20. Ho M, Gallardo E, McKenna-Yasek D, De Luna N, Illa I, Brown Jr RH (2002) A novel, blood-based diagnostic assay for limb girdle muscular dystrophy 2B and Miyoshi myopathy. Ann Neurol 51:129-133

21. Ho M, Post CM, Donahue LR, Lidov HG, Bronson RT, Goolsby H, Watkins SC, Cox GA, Brown RH Jr (2004) Disruption of muscle membrane and phenotype divergence in two novel mouse models of dysferlin deficiency. Hum Mol Genet 13:1999-2010

22. Hoffman EP, Brown RH Jr, Kunkel LM (1987) Dystrophin: the protein product of the Duchenne muscular dystrophy locus. Cell 51:919-928
23. Holzfeind PJ, Grewal PK, Reitsamer HA, Kechvar J, Lassmann H, Hoeger H, Hewitt JE, Bittner RE (2002) Skeletal, cardiac and tongue muscle pathology, defective retinal transmission, and neuronal migration defects in the Large(myd) mouse defines a natural model for glycosylation-deficient muscle-eye-brain disorders. Hum Mol Genet 11:2673-2687

24. Illa I, Serrano-Munuera C, Gallardo E, Lasa A, Rojas-Garcia R, Palmer J, Gallano P, Baiget M, Matsuda C, Brown RH (2001) Distal anterior compartment myopathy: a dysferlin mutation causing a new muscular dystrophy phenotype. Ann Neurol 49:130-134

25. Ling Y, Morgan K, Kalsheker N (2003) Amyloid precursor protein (APP) and the biology of proteolytic processing: relevance to Alzheimer's disease. Int J Biochem Cell Biol 35:1505-1535

26. McKhann G, Drachman D, Folstein M, Katzman R, Price D, Stadlan EM (1984) Clinical diagnosis of Alzheimer's disease: report of the NINCDS-ADRDA work group under the auspices of Department of Health and Human Services Task Force on Alzheimer's disease. Neurology 34:939-944

27. Morris JC (1993) The Clinical Dementia Rating (CDR): current version and scoring rules. Neurology 43:2412-2414

28. National Institute on Aging, Reagan Institute Working Group on Diagnostic Criteria for the Neuropathological Assessment of Alzheimer's Disease (1997) Consensus recommendations for the postmortem diagnosis of Alzheimer's disease. Neurobiol Aging 18(S4):S1-S2

29. Salani S, Lucchiari S, Fortunato F, Crimi M, Corti S, Locatelli F, Bossolasco P, Bresolin N, Comi GP (2004) Developmental and tissue-specific regulation of a novel dysferlin isoform. Muscle Nerve 30:366-374

30. Sharma MC, Goebel HH (2005) Protein aggregate myopathies. Neurol India 53:273-279

31. Spillantini MG, Tolnay M, Love S, Goedert M (1999) Microtubule-associated protein tau, heparan sulphate, and $\alpha$-synuclein in several neurodegenerative diseases with dementia. Acta Neuropathol 97:585-594

32. Yasunaga S, Grati M, Cohen-Salmon M, El-Amraoui A, Mustapha M, Salem N, El-Zir E, Loiselet J, Petit C (1999) A mutation in OTOF, encoding otoferlin, a FER-1-like protein, causes DFNB9, a nonsyndromic form of deafness. Nat Genet 21:363-369 